\title{
FINANCIAL AID FOR POLISH AGRICULTURE AND CHANGES IN ITS SHARE IN THE STRUCTURE OF AGRIBUSINESS
}

\author{
Marian Podstawka, Full Professor ${ }^{1}$ \\ Faculty of Economic Sciences, Warsaw University of Life Sciences - SGGW
}

\begin{abstract}
The study presents the share of agriculture in the structure of agribusiness and presents the forms of support it uses. It was found that agribusiness is characterized by dynamic changes. Against the background of the national economy, its share in labour resources, fixed assets, investment outlays and output and its gross added value is decreasing. As part of Polish agribusiness, agriculture has the dominant share. There is considerable support for agriculture with EU and national financial aid. The largest share of domestic aid constituted subsidies for investment loans and working capital loans.
\end{abstract}

Keywords: agribusiness, financial aid, agriculture JEL codes: Q14, Q18

\section{INTRODUCTION}

The concept of agribusiness has been known in academic literature since the 1950s. It was first introduced to scientific literature in 1957 by I.H. Davis and R.A. Goldberg (Encyclopedia of agribusiness, 1998). In folk Poland in the 1960s and 1970s, this system of structure and dependence was defined as a complex system of food economy. It was especially more about political considerations, with the focus not to imitate western ideas in our economic reality. After 1989, there are no obstacles to using the concept of agribusiness in Poland. Therefore, this term is now freely used in scientific literature, statistics and scientific discussions. The aim of the study is to assess the state of the structure and function of agribusiness and the changes occurring in them. The following research hypotheses were adopted in the study:
1. Changes in agribusiness are derived from processes taking place in the national economy and lessen the role of agriculture.

2. Agriculture is losing (through the market) part of the generated financial surplus for other sectors of the national economy.

3. The scale of interventionism in agriculture is increasing.

\section{AGRIBUSINESS - CONCEPT, SCOPE, SPECIFICITY}

Nowadays, agribusiness is defined as a subsystem of the national economy, created as a result of vertical integration of all elements of the national economy involved in food production. Thus, agribusiness includes: agriculture, fishery, forestry, agri-food industry, industries producing means of production and services for agriculture and other industries involved

${ }^{1}$ Corresponding author: Nowoursynowska 166,02-787 Warsaw, Poland, marian_podstawka@sggw.pl 
in food production, purchase, transport of agricultural products and means of production, trade in readymade food products. Agribusiness considered from the side of the branch-branch structure includes:

- agriculture dealing in the production of raw materials for food production;

- fishing, forestry, which also provide raw materials for food production or ready-made food;

- food industry dealing in the processing of agricultural raw materials and gastronomy;

- industries producing means of production and services for agriculture and food industry;

- trading in agricultural raw materials and readymade food products (wholesale, retail, marketing);

- services provided for agribusiness (financial, transport, communication, information, construction, science, education, consulting).

Agribusiness also includes the production of raw materials for energy purposes, as well as providing services to the environment and the population. Historically speaking, in the early stages of socio-economic development, the production of food was handled by agriculture. Then, other activities were distinguished in this process, such as: agri-food processing, trade in services and industry, and crafts producing means of production for agriculture and food processing. Over time, these separate food production processes began to integrate creating a modern agribusiness consisting of three segments: I - industry producing means of production for agriculture and agri-food industry; II agriculture; III - agri-food industry (Szuba-Barańska, Poczta and Mrówczyńska-Kamińska, 2016).

To sum up, agribusiness is a subsystem of the national economy that from a technological, financial, legal and organisational perspective fuses all those activities that participate in the production of agricultural raw materials, processing and distribution of food and derivative products. Agribusiness can also be defined as a field of knowledge, research and academic didactics: this is mainly about the assessment of changes in the share of agribusiness in the national economy, the assessment of changes in its structure and control mechanisms.

Agribusiness is a subsystem of the national economy, which co-creates the national global product. This product is made up of all departments that are part of agribusiness. At the same time their contribution to the creation of a national global product is different. Through a simplification, we can write the formula defining the role of agribusiness in creating a gross national product as follows:

$$
N P G A=P g l r+P g l p s+\Sigma P g l i \times b i
$$

where:

$N P G A$ - national product of global agribusiness;

$P g l r$ - global production of agriculture;

Pglps - global production of the food industry;

Pgli - global production and this department involved in food production;

bi - coefficient defining the flow of products and services and - this section to agriculture and food industry.

In the case of Poland, the characteristic feature of agribusiness is its dynamic changes. Until 1990, agriculture played a dominant role, in terms of its share in production resources and production. The share of agriculture in agribusiness at that time was 77.2 and $52.5 \%$, respectively (Encyclopedia of agribusiness, 1998). The greater share of agriculture in resources in relation to the share in the production of agribusiness results from the lower productivity of labour and property in it, which is the result of the laws of biology and the market situation.

As regards the restrictions on the size of agricultural production from the unit of area, they result mainly from the specifics of cultivated land. Due to its quality, location and diversity in this respect, the land influences the nature of the activity and financial results obtained from it. These features of agricultural land make it a source of rent. Already A. Smith noticed that running agricultural activity in various places causes various costs and brings different effects. These observations were continued by D. Ricardo, A. Weber and others. Differential rent I arises due to the different quality of agricultural land and its different location in relation to the market. Differential rent II is a relative effect of benefits resulting from differences in the intensity of agricultural management. Another form of rent is urban rent, which is a relative advantage achieved by landowners with a favourable 
location (in academic literature it is referred to as differential rent III). Recently, an environmental income has also been written about (differential rent IV) (Czyżewski, 2009). In this case, the increase in the value of plots may result from environmental conditions characterized by high natural and microclimatic values, etc. In connection with the emergence of transfers under the Common Agricultural Policy there is a capital pension, which is obtained by owners of agricultural land. Capital pensions often occur in combination with benefits resulting from beneficial legislative solutions in the field of social security and taxation. The implementation of pensions resulting from the peculiarities of agricultural land has a fundamental impact on the pace of changes taking place in the agrarian structure. In principle, the possibility of deriving economic, especially capital, and legislative pensions hinders the transfer of land from small farms to development farms. Thus, the occurrence of these pensions delays changes in the whole agribusiness. Agribusiness as a production subsystem of the national economy is characterized by a certain specificity, namely:

- It is a subsystem that produces raw materials and food, without which no other products can be created.

- It is a subsystem that brings together various components, which are characterized by diversified efficiency, effectiveness, diversified sensitivity to external factors of production, and agricultural production is particularly sensitive to them. On the one hand, the specifics of land used for the production of food raw materials and the law of biology cause that in agriculture we have lower productivity of labour and capital in comparison to other components of agribusiness. On the other hand, both agricultural plant and animal production are the most dependent on environmental conditions. In principle, plant production is 'defenseless' in this respect. Producer under unfavourable conditions, suffers almost total losses.

However, in the case of activities that are also dependent on the environment such as construction, transport, etc., in conditions that are not suitable for them, the result is a failure to realize income (profits) and possible small losses.
The biological and technological features of agricultural production mentioned above cause that when it comes to economic relations under agribusiness, they are least beneficial for agricultural raw materials. Their undervaluation is frequently observed. Prices of agricultural raw materials show a tendency of having a smaller share in the prices of ready-made nutrients.

On the other hand, the prices of agricultural production means are re-evaluated against the prices of other products. As a result, the market position of agriculture is systematically deteriorating in relation to other sectors of the national economy, which is additionally strengthened by rigid demand for food.

Consequently, we note the continuing problem of income disparity among farmers in relation to other professional groups. This is the most important determinant of the agrarian issue. In addition, it is worth noting that there is a lack of residential infrastructure in rural areas, or it is much more modest than in cities. There is poorer access of rural population to large stores, public transport, banks, restaurants, stadiums, cinemas, theaters, public administration offices, highways, and underground. The vast majority of this infrastructure was financed from public funds, access to which, in principle, is given only to the urban population.

On the other hand, agriculture provides goods to the public in the form of: landscape, the environment, space for which no compensation is paid. In this situation, agriculture uses systems of intervention from national public authorities and the European Union.

\section{FINANCIAL AID FOR AGRICULTURE}

The amount of aid for agriculture from public funds, both EU and national, is countable and is presented in Table 1. On the other hand, some problems are caused by the valuation of the environmental role of agriculture and the amount of financial surplus flowing from it to non-agricultural departments, which mainly involves urban population.

Data from Table 1 indicate that small amounts of resources were allocated to support fisheries, an amount of just over PLN 4 billion. Agriculture 
Proceedings of the 2018 International Scientific Conference 'Economic Sciences for Agribusiness and Rural Economy' No 1, Warsaw, 7-8 June 2018, pp. 343-350

Table 1. Implementation of agricultural aid in 2005-2017 (PLN billion)

\begin{tabular}{|l|c|c|c|c|c|c|c|c|c|}
\hline Form of aid & 2010 & 2011 & 2012 & 2013 & 2014 & 2015 & 2016 & 2017 & $\begin{array}{c}\text { From the } \\
\text { beginning } \\
\text { of its launch }\end{array}$ \\
\hline Direct support & 10.2 & 12.9 & 10.7 & 14.8 & 14.1 & 14.7 & 21.3 & 14.2 & 158.7 \\
\hline PROW 2004-2006 & - & - & - & - & - & - & - & - & 10.9 \\
\hline PROW 2014-2020 & - & - & - & - & 0.6 & 0.4 & 3.8 & 4.1 & 8.9 \\
\hline $\begin{array}{l}\text { The common } \\
\text { organization of the } \\
\text { markets in fruit and } \\
\text { vegetables }\end{array}$ & 0.7 & 1.1 & 1.7 & 1.8 & 1.1 & 0.7 & 0.3 & 0.1 & 8.0 \\
\hline Aid for fishery & 0.4 & 0.8 & 0.8 & 0.8 & 0.8 & 0.4 & 0.1 & 0.1 & 4.2 \\
\hline SAPART program & - & - & - & - & - & - & - & - & 4.5 \\
\hline Total EU aid & 19.7 & 24.8 & 24.8 & 28.2 & 26.4 & 28.9 & 25.5 & 18.7 & 278.8 \\
\hline National aid & 0.8 & 0.8 & 1.1 & 0.7 & 0.6 & 0.9 & 0.5 & 0.8 & 22.5 \\
\hline $\begin{array}{l}\text { Total } \\
\text { EU + Poland }\end{array}$ & 20.5 & 25.6 & 25.9 & 28.9 & 27.0 & 29.8 & 26.0 & 19.5 & 301.3 \\
\hline
\end{tabular}

Source: information on the implementation of ARMA's tasks, February 2018.

received a total of PLN 297 billion support from EU and national assistance. Domestic aid constituted only $7.5 \%$ of total aid. The assistance from the European Union was dominant. More than half of this total aid has been earmarked for direct support, an amount of over PLN 158 billion (52.2\%). Support under the RDP in 2004-2017 amounted to over 95 billion. $\mathrm{zl}$ - which constituted about $31 \%$ of total support. Table 2 presents the level and structure of direct support granted to Polish agriculture in 2004-2017.

The information contained in Table 2 shows that uniform area payments constitute the dominant element of direct support. They accounted for over $60 \%$ of this type of agricultural aid. The second item is occupied by complementary area payments for other plants. The share of this type of support amounted to less than $18 \%$ of direct aid. Other types of direct support are small shares. What is noteworthy is the huge dispersion of direct aids. This increases the costs of servicing farmers through ARMA and creates opportunities for dishonest activities. Noteworthy is also extensive national assistance. ARMA from national funds provides financial assistance in the scope of:

- implementation of investments and processing in farms;

- creation or enlargement of farms by young farmers,

- resumption of production on farms;

- education of rural residents;

- collection of transport and utilization of fallen animals.

The information contained in Table 3 shows that almost half of the national aid was allocated for subsidies to investment loans. A significant share is subsidies for disaster and revolving loans. Other types of domestic aid are very much dispersed.

\section{POLAND'S AGRIBUSINESS STRUCTURE AND ITS CHANGES}

The structure of agribusiness is changing both in Poland and in other developed economies. This is due to the development processes of the entire economy of a given country and a group of countries. Together 
Table 2. Level and structure of direct support for Polish agriculture in 2004-2017 (PLN million)

\begin{tabular}{|c|c|c|c|c|c|c|c|c|}
\hline Types of direct support & $2004-2011$ & 2012 & 2013 & 2014 & 2015 & 2016 & 2017 & Total \\
\hline JPO* & 43661 & 10214 & 11442 & 12676 & 6284 & 6414 & 4798 & 95491 \\
\hline UPO** other plants & 25316 & 1643 & 965 & - & - & - & - & 27925 \\
\hline UPO hops & 19 & 2 & 2 & 2 & 3 & 3 & 3 & 34 \\
\hline UPO animal payments & 3893 & 471 & 338 & - & - & - & - & 4703 \\
\hline UPO energy payments & 30 & - & - & - & - & - & - & 30 \\
\hline $\begin{array}{l}\text { UPO for raw tobacco } \\
\text { producers }\end{array}$ & - & 180 & 184 & 159 & 153 & 144 & 111 & 931 \\
\hline Payments for starch & - & 38 & 37 & 36 & 36 & 37 & 24 & 207 \\
\hline Payments for tomatoes & - & - & - & - & 17 & 18 & 6 & 41 \\
\hline Payments for flax & - & - & - & - & 2 & 2 & 2 & 6 \\
\hline Payments for hemp & - & - & - & - & 0.4 & .4 & 0.1 & 0.9 \\
\hline $\begin{array}{l}\text { Payments for fruit and } \\
\text { vegetables }\end{array}$ & 107 & 27 & 28 & 27 & - & - & - & 189 \\
\hline Payments for soft fruits & 275 & 78 & 46 & 46 & 62 & 64 & 31 & 602 \\
\hline Payments for sugars & 3343 & 648 & 654 & 652 & 341 & 346 & 227 & 6212 \\
\hline Payments for legumes & 88 & 134 & 144 & 152 & 273 & 287 & 207 & 1288 \\
\hline Payments for greening & - & - & - & - & 4252 & 4340 & 3137 & 11719 \\
\hline Payments to farmers & - & - & - & - & 264 & 276 & 170 & 709 \\
\hline Payments for cows & 233 & 165 & 162 & 154 & 627 & 643 & 509 & 2488 \\
\hline Payments for sheep & 12 & 9 & 9 & 10 & 18 & 19 & 13 & 91 \\
\hline Payments for cattle & - & - & - & - & 702 & 721 & 564 & 1987 \\
\hline Payments for goats & - & - & - & - & 1 & 1 & 1 & 3 \\
\hline Payments for tobacco & - & 118 & 120 & 119 & - & - & - & 358 \\
\hline TOTAL & 76980 & 13734 & 14133 & 14186 & 14314 & 14621 & 10784 & 158755 \\
\hline
\end{tabular}

* JPO - single area payment.

** UPO - national complementary area payments.

Source: as in Table 1.

Table 3. The level and structure of national agricultural aid granted in 1994-2017

\begin{tabular}{|l|c|}
\hline Type of national support & Amount (PLN million) \\
\hline Additional payments for investment loans & 11775 \\
\hline Subsidies for disaster and revolving loans & 5262 \\
\hline Equivalents for the afforestation of forest lands & 618 \\
\hline Utilization of dead animals & 946 \\
\hline Disaster relief & 909 \\
\hline Support for the development of technical infrastructure of villages & 1039 \\
\hline EXTRA payments for milk & 692 \\
\hline Loans for jobs & 258 \\
\hline Together & 22474 \\
\hline
\end{tabular}

Source: as in Table 1. 


\begin{tabular}{|c|c|c|c|c|c|c|}
\hline \multirow{3}{*}{ 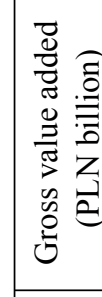 } & : & 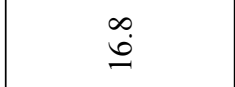 & 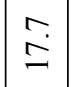 & $\stackrel{\infty}{\vec{\sim}}$ & ?ై &  \\
\hline & $\stackrel{n}{\stackrel{n}{N}}$ & in & \begin{tabular}{c|}
0 \\
$\infty$ \\
$\infty$ \\
$\alpha$
\end{tabular} & 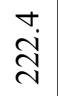 & $\begin{array}{l}n \\
\stackrel{n}{\infty} \\
\infty \\
n\end{array}$ & $\stackrel{\infty}{\stackrel{\infty}{\Theta}}$ \\
\hline & 곡 & in & $\overrightarrow{\mathrm{g}}$ & $\begin{array}{l}\vec{\partial} \\
\dot{\Delta} \\
\stackrel{\sim}{े}\end{array}$ & $\underset{m}{\stackrel{n}{*}}$ & $\stackrel{\vec{I}}{ }$ \\
\hline \multirow{6}{*}{ 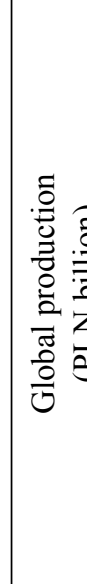 } & 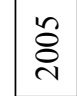 & $\stackrel{i}{i}$ & $\begin{array}{l}m \\
\dot{B}\end{array}$ & $\begin{array}{l}\stackrel{+}{0} \\
\stackrel{\Delta}{\Xi}\end{array}$ & $\stackrel{\widehat{o}}{\stackrel{o}{\sim}}$ & 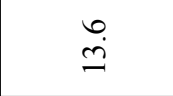 \\
\hline & ¿্ণ & $\stackrel{m}{m}$ & $\begin{array}{l}\dot{0} \\
\dot{i n}\end{array}$ & $\vec{\delta}$ & $\stackrel{ナ}{\stackrel{\Delta}{\infty}}$ & $\stackrel{\circ}{\dot{m}}$ \\
\hline & $\stackrel{n}{\tilde{N}}$ & $\vec{n}$ & $\dot{m}$ & $\stackrel{m}{\infty}$ & $\stackrel{\vec{\infty}}{\stackrel{\sim}{-}}$ & $\because$ \\
\hline & בับ & $\vec{n}$ & $\stackrel{n}{+}$ & $\vec{\infty}$ & $\vec{I}$ & $\stackrel{\circ}{i}$ \\
\hline & 商 & ナ & $\stackrel{\vec{i}}{\mathrm{i}}$ & ชี & 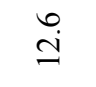 & $\stackrel{8}{\circ}$ \\
\hline & ڤัণ & $\stackrel{\nabla}{m}$ & $\vec{i}$ & $\stackrel{\infty}{+}$ & $\stackrel{m}{\circ}$ & 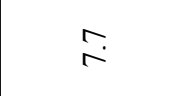 \\
\hline \multirow{4}{*}{ 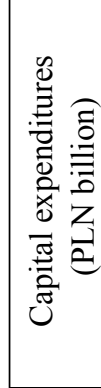 } & 公 & $\vec{n}$ & in & $\stackrel{m}{\infty}$ & $\stackrel{\curvearrowright}{\infty}$ & $\stackrel{n}{?}$ \\
\hline & ते & $\vec{n}$ & $\because$ & $\vec{\infty}$ & $\vec{I}$ & $\stackrel{i}{i}$ \\
\hline & 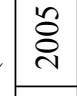 & $\stackrel{\circ}{+}$ & $\stackrel{\vec{i}}{\mathrm{i}}$ & ชુ & $\begin{array}{l}0 \\
\stackrel{I}{J}\end{array}$ & $\stackrel{\circ}{\circ}$ \\
\hline & ¿্ণ & $\dot{m}$ & $\vec{i}$ & $\stackrel{\infty}{+}$ & $\stackrel{m}{\varrho}$ & 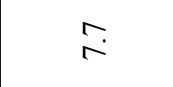 \\
\hline \multirow{4}{*}{ 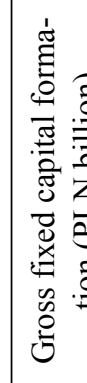 } & $\stackrel{\text { in }}{n}$ & $\vec{\circ}$ & \begin{tabular}{|l}
$\stackrel{0}{0}$ \\
$\stackrel{0}{2}$
\end{tabular} & 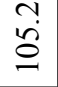 & बें & $\dot{\infty}$ \\
\hline & ĩ & $\overrightarrow{\dot{n}}$ &  & $\stackrel{\circ}{\dot{L}}$ &  & $\stackrel{\circ}{\circ}$ \\
\hline & 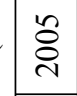 & $\begin{array}{l}\stackrel{\circ}{+} \\
\stackrel{\infty}{+}\end{array}$ & $\overrightarrow{\mathrm{j}}$ & 苞 & $\overline{\vec{i}}$ & $\stackrel{\text { I }}{\text { I }}$ \\
\hline & ఏ్రి & $\overrightarrow{+}$ & $\overrightarrow{\dot{\theta}}$ & $\begin{array}{l}\infty \\
\dot{+} \\
+\end{array}$ & 范 & $\stackrel{+}{\stackrel{\oplus}{~}}$ \\
\hline \multirow{4}{*}{ 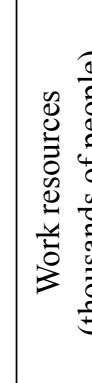 } & $\stackrel{n}{\tilde{i}}$ & 志 & $\begin{array}{l}\mathbf{D} \\
\stackrel{\infty}{\sim} \\
\stackrel{n}{n}\end{array}$ & $\underset{m}{\tilde{m}}$ & $\vec{i}$ & $\stackrel{\vec{i}}{\hat{i}}$ \\
\hline & בับ & 芦 &  & f & ڤે & $\overline{\dot{A}}$ \\
\hline & 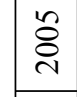 & 导 & 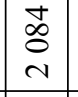 & $\underset{b}{\infty}$ & $\begin{array}{l}+ \\
\stackrel{+}{\circ} \\
\text { సे }\end{array}$ & 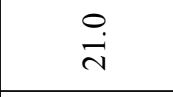 \\
\hline & : & ó & $\mid \begin{array}{c}\tilde{D} \\
\tilde{m}\end{array}$ & i̊ & $\underset{\substack{+++}}{F}$ & సี \\
\hline 0 & 2 & 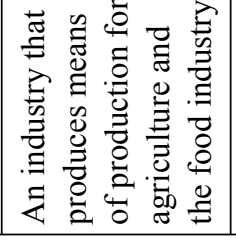 & 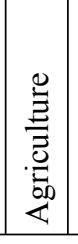 & 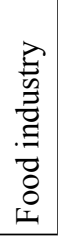 & 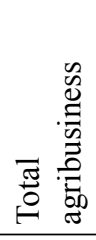 & 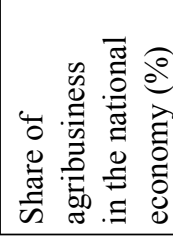 \\
\hline
\end{tabular}


with these changes in the agribusiness structure, the share in global production and gross added value of the food industry and trade is growing. The share of agriculture itself (previously indicated for this reason) and the supply industry are decreasing. It is worth pointing out that the share of all agribusiness in the national economy is decreasing, with a clear increase in production realized as part of it. Relevant information is presented in Table 4.

Data from Table 4 indicate that agriculture has the largest share in the employment structure in agribusiness in Poland. Employment in agriculture is about three times higher than total in the food industry and the industry producing means of production for agribusiness. As for fixed assets, in agriculture they are almost the same as in the other two components of Polish agribusiness. The dominance of agriculture in two basic factors of production, against the background of two industries, does not translate into its economic results. The food industry is definitely the best in this respect. While engaging large amounts of production factors, agriculture achieves the weakest income results relative to them. Agriculture also has a small, within the framework of agribusiness, level and share in terms of investment expenditures. All this is diminishing the role of agribusiness in the national economy. This relative reduction concerns both the means of production and the economic and financial results. The greatest relative decrease in agribusiness in the economy is observed on the labour resources side. In the years 2000-2015, they decreased by over 1.5 million people. Work resources located in agribusiness decreased by more than $10 \%$, from $32.2 \%$ in 2000 to $21.7 \%$ in 2015 .

As for the assets of fixed assets, its absolute value is increasing. From PLN 194 billion in 2000 to 294.9 billion in 2015. However, in relation to the entire national economy, a decline from 13.4 to $8.7 \%$ has been observed over the years. A similar pattern exists in the case of capital expenditures. These increased in the absolute dimension, from PLN 10.3 billion in 2000 to PLN 18.7 billion in 2015, whilst their relative share decreased slightly from $7.7 \%$ in relation to the national economy in 2000 to $7.5 \%$ in 2015 .

In the case of global production in absolute terms, a double increase can be observed. With almost
PLN 190 billion in 2000 to over PLN 380 billion in 2015. Despite this absolute increase, the global production of all agribusiness recorded a decline in the surveyed years from $13 \%$ in 2000 to $10.8 \%$ in 2015 , against the background of the entire national economy. A similar situation can be observed in the case of gross added value, which has almost doubled in absolute terms, from PLN 56.3 billion in 2000 to PLN 107.2 billion in 2015, despite its absolute increase, its share in the entire national economy decreased from $8.5 \%$ in 2000 to $6.6 \%$ in 2015 .

\section{CONCLUSIONS}

1. Agribusiness is characterized by dynamic changes. Against the background of the national economy, its share in labour resources, fixed assets, investment outlays and output and its gross value added is decreasing. Although the absolute values of these categories of agribusiness is growing, in addition to labour resources, these decreased in the years $2000-2015$ by about 1.5 million people.

2. As part of Polish agribusiness, agriculture in the production factors (labour resources, fixed assets) has a dominant share. However, in terms of output (global production, gross value added), the largest share is observed in the food industry.

3. Noteworthy is the significant support of agriculture with EU and national financial aid. In total agriculture received, in 2005-2017, PLN 300 billion, which gives about PLN 27 billion annually. Of this assistance, 93\% constituted EU aid, only 7\% was national aid.

4. The largest share of domestic aid were constituted by subsidies for investment loans and for loans under loans and working capital loans. Other types of domestic aid as well as EU aid were characterized by considerable dispersion.

5. This aid is a compensation for agriculture for its contribution to the well-being of the environment, the outflow of financial surplus through the market mechanism to non-agricultural sectors and the inability of the agricultural population to use the so-called civilization rent.

\section{REFERENCES}

1. Czyżewski, B. (2009). Współczesne teorie renty gruntowej, ich geneza i znaczenie dla Wspólnej Polityki Rolnej w Unii Europejskiej (Contemporary theories 
of land rent, their origin and significance for the Common Agricultural Policy of the EU). Zeszyty Naukowe SGGW, Polityki Europejskie, Finanse i Marketing, 2 (51), pp. 39-55.

2. Encyklopedia agrobiznesu [Encyclopedia of agribusiness]. Fundacja Innowacji. Wyższa Szkoła Społeczno-Ekonomiczna, Warszawa 1998.

3. Mrówczyńska-Kamińska, A. (2014). Struktura agrobiznesu w Polsce i jego znaczenie w gospodarce w kon- tekście integracji z UE [Structure of agribusiness in Poland and its importance in the economy in the context of integration with the EU]. Prace Naukowe Uniwersytetu Ekonomicznego we Wrocławiu, 360, pp. 47-54.

4. Szuba-Barańska, E., Poczta, W., Mrówczyńska-Kamińska, A. (2016). Zmiany struktur agrobiznesu Polski i Niemiec [Changes in the agribusiness structures of Poland and Germany]. Roczniki Naukowe SERiA, 18 (6), pp. 216-220. 